\title{
Observations on the Architecture of the Tomb of Horhotep in Western Thebes
}

\author{
PATRYK Chudzik, Mariusz CABAN
}

\begin{abstract}
The article describes the architecture of the tomb of Horhotep, an official at the court of Senwosret I, which is situated at the necropolis of North Asasif in Western Thebes. The structure was built in the row of sepulchral complexes, which belonged to high-ranking officials from the times of the reign of Mentuhotep II. The tomb belongs to the rock tomb type. The layout and shape of the chambers and passages corresponds with the local Theban tradition of the construction of private sepulchral complexes. The exceptional character of the complex can be seen in the layout of the parts carved in the bedrock. As a result of the research into the architecture of the tomb, two phases of its development have been distinguished. The first was associated with the carving of the classic tomb for Horhotep. In the second phase, another cult chapel and the second burial chamber were added, where, as one can only speculate, the son of the official was supposed to be buried.
\end{abstract}

Keywords: Western Thebes, Horhotep, Middle Kingdom Egypt, rock-cut tomb, architecture, MMA 513, TT 314

Patryk Chudzik, Institute of Archaeology University of Wrocław, Wrocław; pchudzik71@gmail.com

Mariusz Caban, Faculty of Architecture, Wrocław University of Technology, Wrocław; mariusz.caban@gmail.com

The tomb of Horhotep (MMA 513/TT 314) is located on the north slope of the Asasif necropolis (Fig. 1). ${ }^{1}$ This part of the Theban necropolis, particularly during the reign of Nebhepetre Mentuhotep II, was assigned for high-ranking royal officials. ${ }^{2}$ Most mortuary

\footnotetext{
${ }^{1}$ Asasif Project archaeological research was launched in season 2013/2014. The works are conducted as part of the programme of the Polish-Egyptian Archaeological-Conservation Mission at the Temple of Hatshepsut at Deir el-Bahari, under the auspices of the University of Wroclaw and the Polish Centre of Mediterranean Archaeology of the University of Warsaw.

2 Mortuary complexes of Khety (MMA 508/TT 311) and Henenu (MMA 510/TT 313) were located in the western part of North Asasif. The eastern part comprises the tomb of an official called Meru (MMA 517/TT 240). This area of the necropolis is supposedly also the place where vizier called Bebi was buried (MMA 509(?)) (Allen 1996: 12; 2003: 21; Chudzik 2015: 240-241).
} 


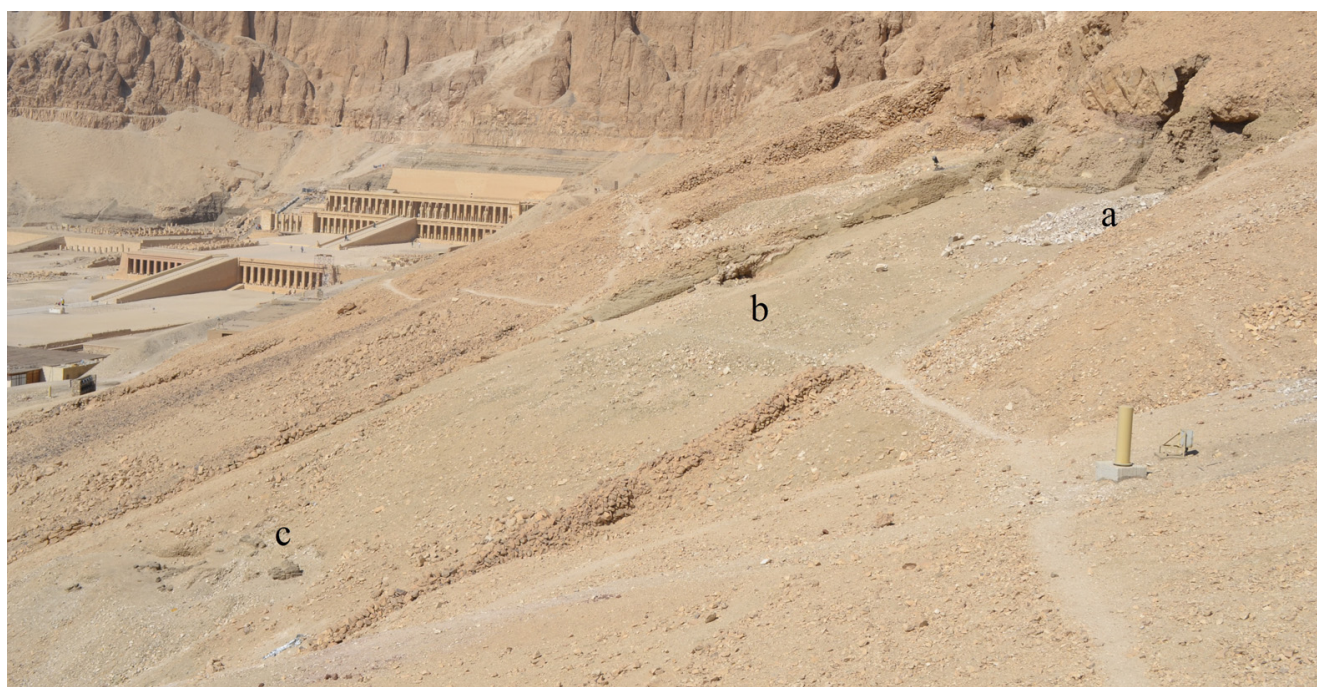

1. Courtyard of Horhotep's tomb complex: a. tomb entrance, b. accompanying tomb, c. mud brick shrine (Phot. P. Chudzik).

complexes are associated with the beginning of that period. Only a few others were built slightly later, mainly during the reigns of the Twelfth Dynasty rulers. The tomb of Horhotep, 'the guardian of the royal seal', who lived in the times of Kheperkare Senwosret I (see below, footnote 8), is one of them.

\section{ARCHITECTURE}

The mortuary complex of Horhotep is situated to the east of an earlier tomb, MMA 512, from the times of the Middle Kingdom. ${ }^{3}$ It can be classified as a corridor tomb type IIa. ${ }^{4}$ The complex described here is divided into two main parts: the courtyard, located on the slope, and the corridors and rooms carved in the rock.

The courtyard is of a trapezoid shape and tapers upwards in north-western direction (Fig. 2). It was marked with a façade, which features the entrance to the tomb and lateral walls on the east and west. The façade and the lateral walls in the upper part of the courtyard were constructed from mud bricks. There are alternating courses of headers and stretchers in the structure of the lateral walls. Such a type of brickwork was one of the most common techniques of erecting brick structures in Egypt. Only the headers can be seen in the face of the façade. The brick walls were covered with mud plaster and painted

${ }^{3}$ Chudzik 2015: 241-244. See the wooden stele of Nebseny and his wife Henenu discovered in the tomb MMA 512 (Hayes 1990: 330, Fig. 218; MMA 26.3.237). The object was definitely fashioned in a local Theban style, characteristic for the rulers of the Eleventh Dynasty.

${ }^{4}$ According to Arnold's typology (Arnold 1971: 43-46). Type IIa is represented in Western Thebes by tomb complexes which are located mainly at the necropolis of North Asasif, as well as by tombs P and T, located on the bottom of the wadi (DAIK excavations: Arnold 1971: 46). 


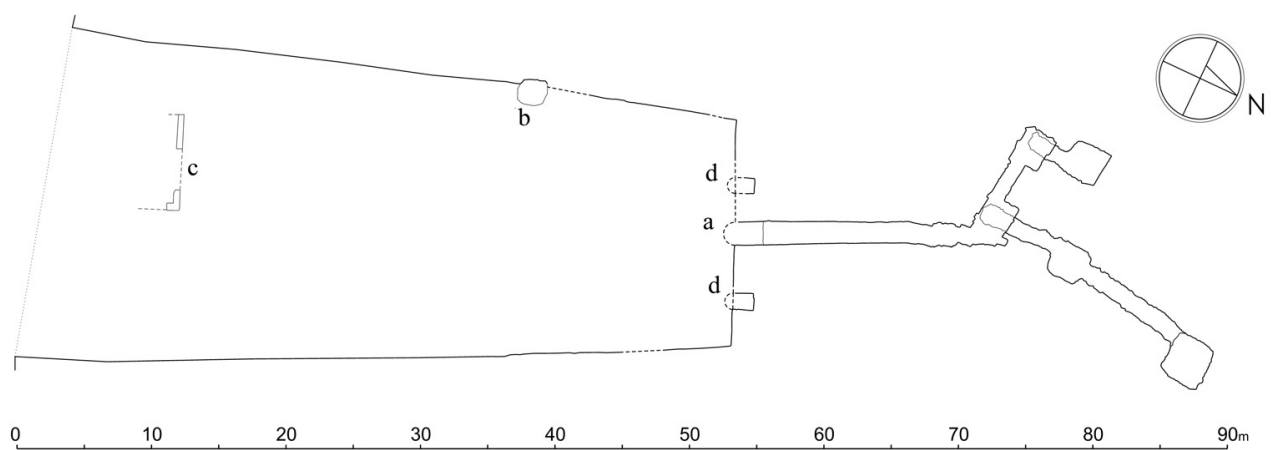

2. Plan of Horhotep's funerary complex: a. tomb entrance, b. accompanying tomb, c. mud brick shrine, d. niches on both sides of the main entrance (Drawing: M. Caban).

white. This was done not only for aesthetic reasons, but - above all - it protected the brick structure from the elements. ${ }^{5}$

There was an entrance to a long corridor situated in the central part of the façade (Figs 1: a, 2: a). Niches with barrel vaults were built on both sides of it (Figs 2: d, 3, 5), and their walls were also covered with mud plaster and painted white. A negative left by a small rectangular stone basin was preserved in the western niche (Fig. 5). The vessel was aligned with the north-south axis and served for ritual purification. ${ }^{6}$

The lateral walls in the lower portion of the courtyard were built from locally found stones without mortar. In the 2013 season the Polish mission discovered the remains of a brick structure between them, near the entrance to the courtyard. ${ }^{7}$ It was a rather small chapel used for a short time after Horhotep's death (Figs 1: c, 2: c). It should be emphasized that the building had never been finished. Some bricks unearthed at that place, which clearly did not constitute a part of the structure, should probably be considered as building material prepared at the construction site of the tomb. Moreover, next to one of the walls, there was a peg (Fig. 4), still thrust into the ground, which had been used to stretch a rope in the past. Even though the building had never been completed, it was confirmed that $k a$-priests had made offerings for the deceased. ${ }^{8}$

An accompanying tomb was discovered in the western part of the courtyard (Figs 1: b, 2: b) in the course of research in $2013 .{ }^{9}$ The entrance to the tomb shaft, $1.8 \mathrm{~m}$ wide, was situated in the bedrock under the brick wall of the courtyard. ${ }^{10}$ The entrance to the chamber or embalming materials chamber was found at a distance of approx. $3 \mathrm{~m}$ to the east of the

${ }^{5}$ Arnold 2003: 34.

${ }^{6}$ For purification ritual, see: Sauneron 2000: 36, 88; for the stone basin, see: Hölzl 2005: 309ff.

7 Chudzik 2015: 243, Figs 6-7; 2016a: 100-101, Figs 57-59.

${ }^{8}$ The fill contained hundreds of fragments of clay vessels, a fragment of a limestone altar and a flint 'knife'. Small ovoid jars from the fill are dated to the times of Kheperkare Senwosret I.

${ }_{9}$ Chudzik 2015: 243-244.

10 The works in the accompanying tomb were finished at a depth of $2.5 \mathrm{~m}$ in season $2013 / 2014$. They will be resumed in the coming seasons. 


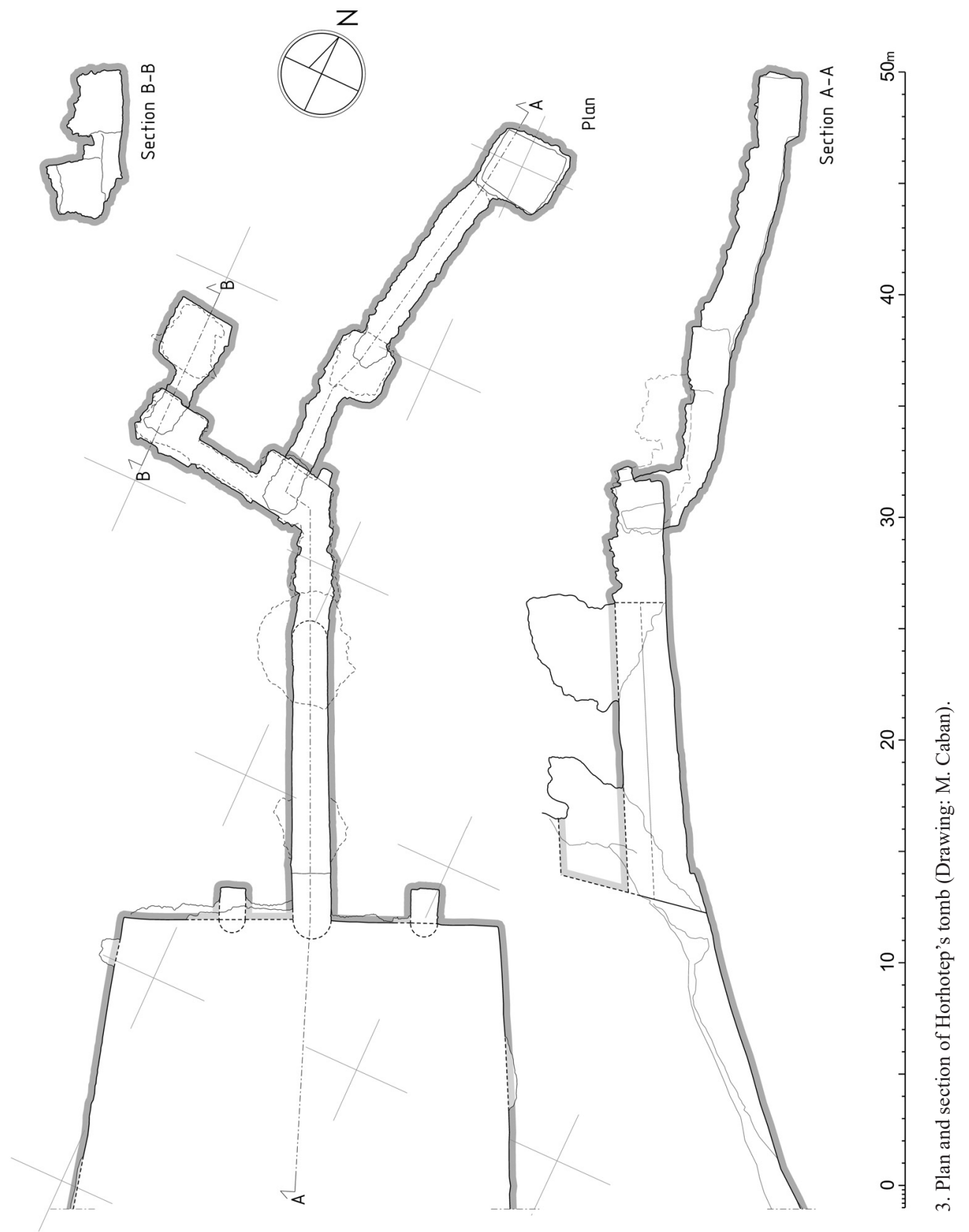


4. Wooden peg by the shrine corner (Phot. P. Chudzik).

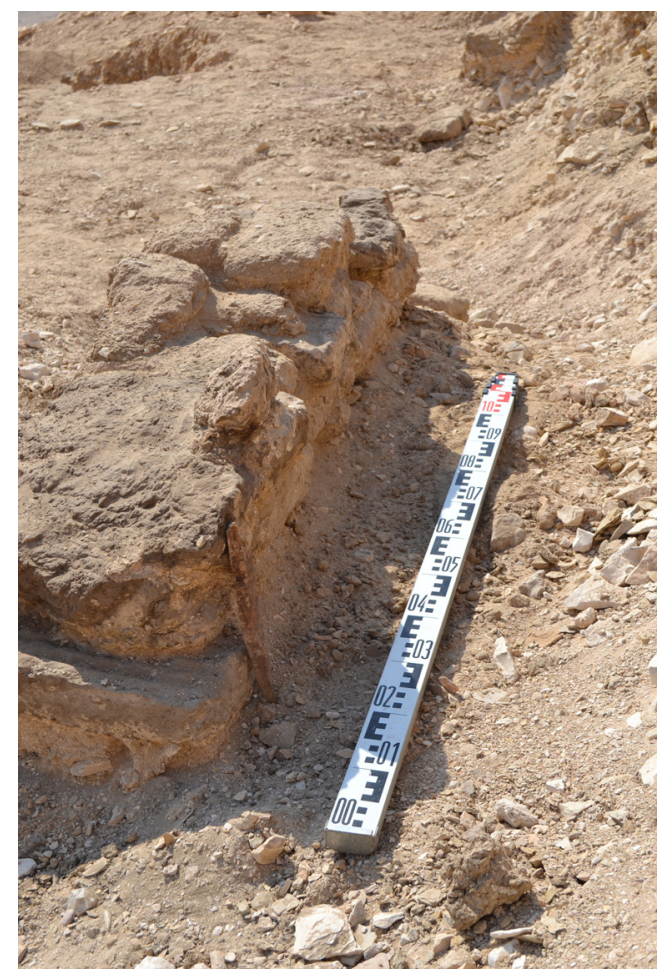

courtyard wall. ${ }^{11}$ Its upper edge was located at a depth of $1.5 \mathrm{~m}$ below the lever of the courtyard. The chamber, c. $2.5 \mathrm{~m}$ long, was aligned with north-south axis. The examination of the fill of the shaft revealed material from the Middle Kingdom as well as from the Late period.

The entrance in the middle of the brick façade of the main tomb is the initial part of a long corridor leading into the bedrock (Fig. 3). The corridor started with a threshold, $0.38 \mathrm{~m}$ high, carved in the rock, which marked the level of the corridor's floor. The structure, $c .18 \mathrm{~m}$ long and $2.5 \mathrm{~m}$ wide, is aligned with the axis of the courtyard. The walls of the corridor were constructed from mud brick and topped with a barrel vault (Fig. 6). The brick walls and the vault were probably supposed to protect visitors to the tomb from the rock pieces coming off the gebel. Nevertheless, a large fragment of the rock dropped from the ceiling at a distance of $c .8 \mathrm{~m}$ from the entrance and caused damage to the brick construction. As a consequence, only the lower part of the walls has been preserved.

The barrel vault, with a half-brick thickness, was supported by the walls of the corridor (Fig. 6). It consisted of courses of bricks laid vertically without a lap. Such a technique of shaping the ceiling was extremely rare in Thebes during the Middle Kingdom. ${ }^{12}$ The barrel

\footnotetext{
${ }^{11}$ It is possible that the shaft, found under the courtyard wall, leads to another tomb.

12 Tomb no. MMA 801 is another example of a tomb with a surviving barrel vault. It is located to the south of the courtyard of the temple-tomb complex of Nebhepetre Mentuhotep II at Deir el-Bahari (see: PM I², map X).
} 


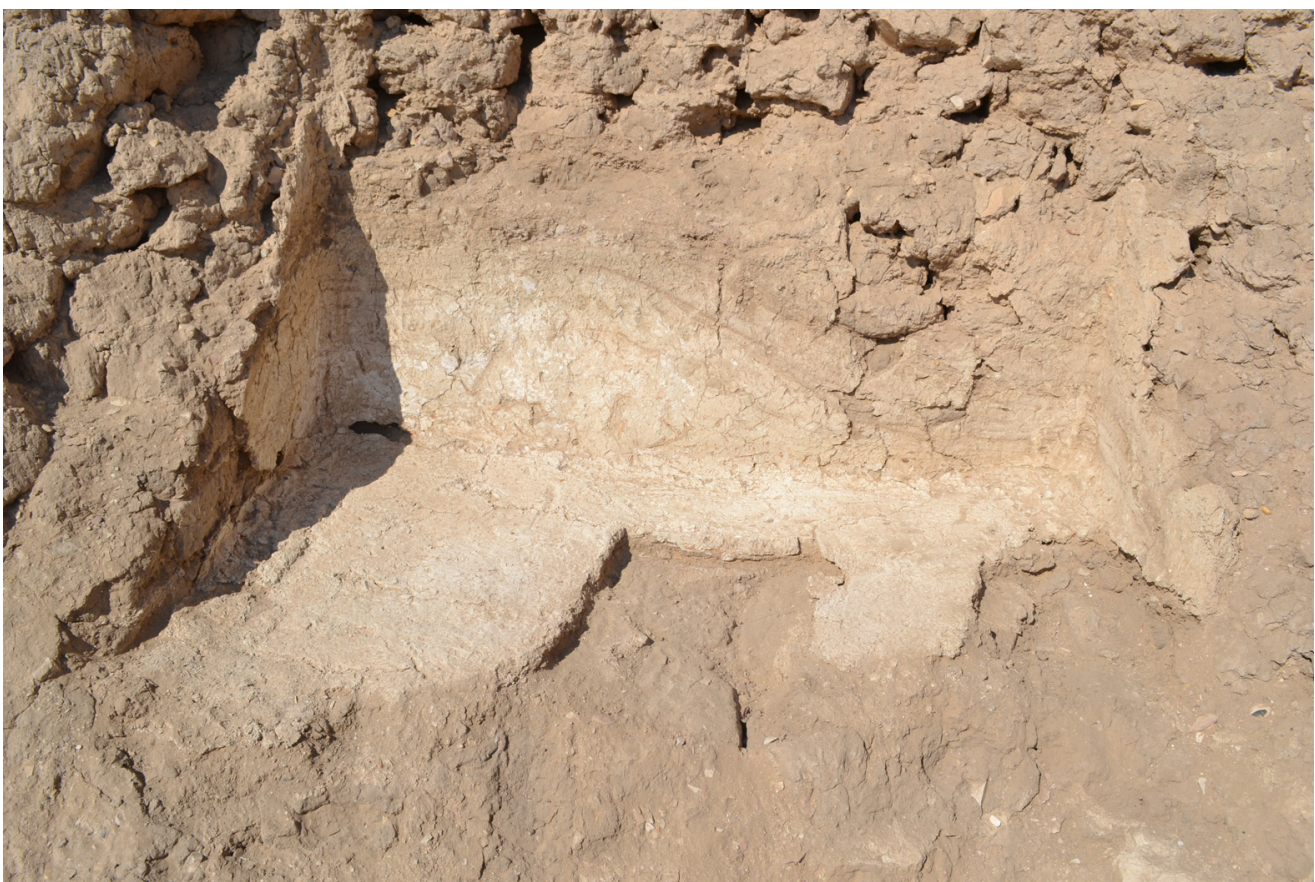

5. Western niche of the façade with a negative left by a small rectangular stone basin (Phot. P. Chudzik).

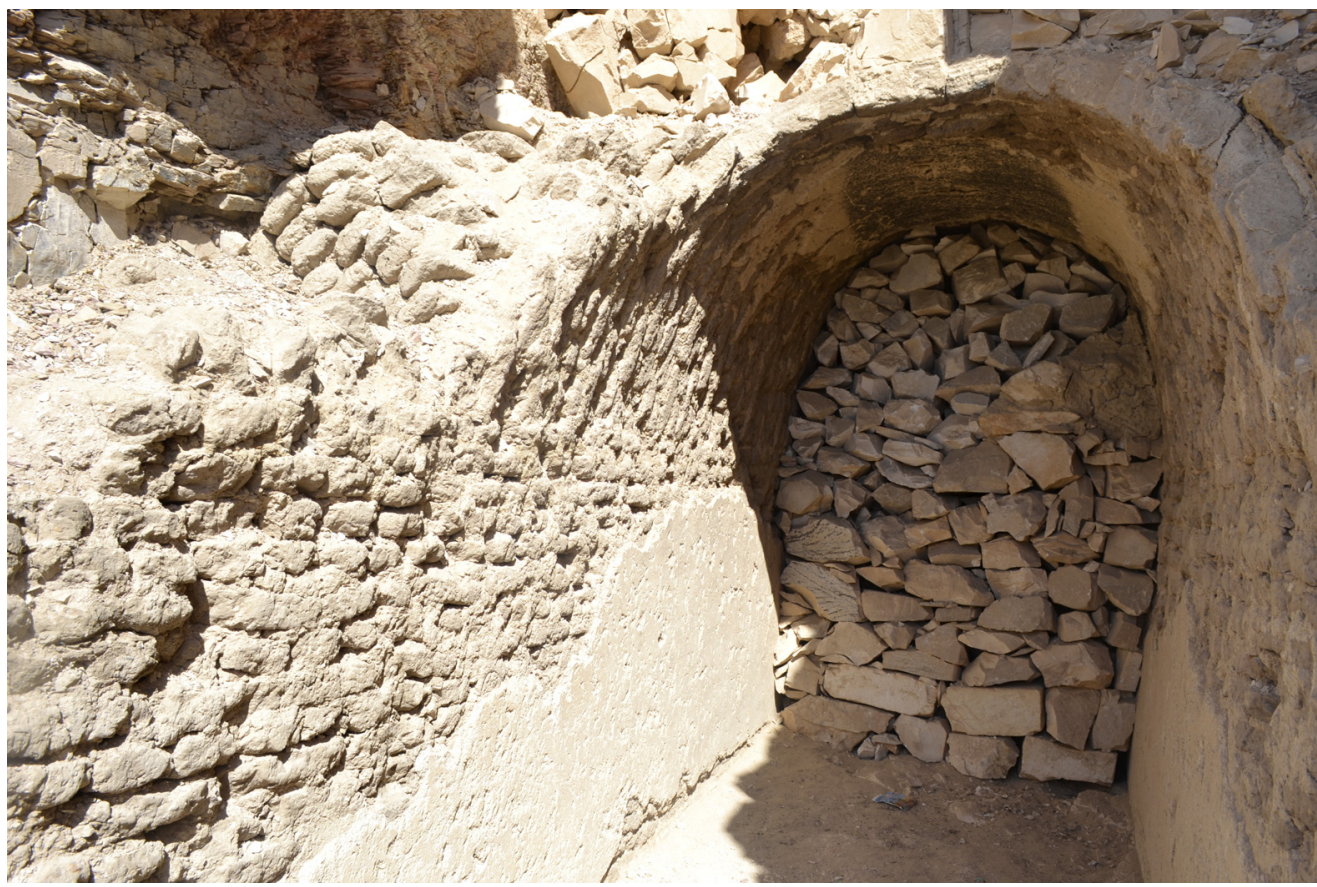

6. Mud brick walls with a barrel vault in the entrance corridor (Phot. P. Chudzik). 
vault in the tomb of Horhotep, together with the white plaster, was preserved along the first $8 \mathrm{~m}$ of the corridor. There were no marks of decoration left on the fragments of the plaster.

At the end of the long corridor leading from the entrance there was a cult chapel (Fig. 3). It was a chamber with a roughly square floor, whose orientation (north-south) was slightly changed in regard to the corridor. A small niche, c. $0.5 \mathrm{~m}$ wide, $0.5 \mathrm{~m}$ deep and $0.75 \mathrm{~m}$ high, was carved in the northern wall of the room. It pointed north, corresponding with the orientation of the chapel. The niche was formed at a height of $1.6 \mathrm{~m}$ above the floor level. Remains of plaster were preserved around its edge, which indicated an existence of a wooden frame. The inner part of the niche was also covered with white plaster. The research conducted so far has not revealed any clues concerning its function. Nevertheless, it could be suggested that the niche was designed for a statuette representing the tomb owner.

The entrance to the burial portion of the complex was located in the floor of the chapel (Fig. 3). That part started with a short, sloping passage, at the end of which there was a chamber with a square floor, carved in the rock. The entrance to the room was situated on the western side of its south wall. Such location of the entrance is typical of Theban tombs dated to the Middle Kingdom. However, the north wall featured the entrance to another descending corridor, which led through the bedrock. It might suggest that the room could have functioned as a false burial chamber, similar to the ones known from the tomb of the 'overseer of sealed goods' Khety (MMA 508/TT 311). ${ }^{13}$ Still another sloping passage, a longer one, was formed along the axis of the room, where it issued from, and led north to the actual burial chamber. The chamber, of a regular shape, opened on the right of the exit from the descending corridor. The properties of the rock in that place made it impossible to put any decoration on its surface, and for that reason, walls were built of limestone and covered with offering lists and religious texts. The beautifully decorated burial chamber of Horhotep was discovered by G. Maspero in the nineteenth century, and then transferred to the Egyptian Museum in Cairo as one of the examples of the mastery possessed by ancient artisans. ${ }^{14}$ The exceptional style of decorations in the Middle Kingdom tomb of Horhotep could not have been missed and left uninscribed by Ch. Wilbour, who visited Thebes in $1883 .{ }^{15}$

The cult chapel of Horhotep was connected with another room by means of a transverse corridor (Fig. 3). An entrance in the western wall of the chapel opened to a short corridor ( $2.3 \mathrm{~m}$ long) that led to a chamber with a square floor of cultic function(?), like the one described above. In the western part of the chapel, in its floor, there was an entrance to a short sloping passage. Another room of a regular shape was carved at the end of the corridor. The entrance opened in the eastern part of its south wall. That room possibly served as another burial chamber.

\footnotetext{
13 Winlock 1923: 14-19; 1942: 68-71.

14 Maspero 1889: 134; 1906: 84-88; Lacau 1904: 42-56; Soliman 2009: 128-129.

15 Capart (Ed.) 1936: 222-223.
} 


\section{CONCLUSION}

The tomb of Horhotep represents a unique style of mortuary architecture from the times of the Middle Kingdom, characteristic for the sepulchral complexes of high officials in Western Thebes. Tombs with long entrance corridors leading to the carved cult chapels are attested from the times of Nebhepetre Mentuhotep II. The architectural solutions of the temple-mortuary complex of Mentuhotep II at Deir el-Bahari were a combination of traditional elements and new concepts, which was successfully copied by local high-ranking individuals in their sepulchral complexes. ${ }^{16}$

Mortuary complexes of the highest-ranking officials at the Theban necropolis in the times of the Middle Kingdom served for individual burials. Nevertheless, in some cases, the courtyards featured accompanying tombs, assigned for officials of a lower rank, who were aides of the one buried in the central tomb. Their relationship during their lifetimes could be best understood by the distribution of particular tombs within the complexes. The associated tomb in the sepulchral complex built for Horhotep was situated near the wall of the courtyard, more than $10 \mathrm{~m}$ from the entrance to the main one. It implies the lower rank - in relation to Horhotep - of the official buried in the associated tomb.

Despite the fact that the tomb of Horhotep is regarded as a typical sepulchral complex of the high officials from the Middle Kingdom in Western Thebes, certain architectural features suggest its unique character. A tomb plan described as T-shaped was typical of private Theban tombs from the beginning of the Middle Kingdom. In the early phase of development, in accordance with the generally accepted layout, they consisted of a long corridor leading to the cult chapel, with an entrance to a descending corridor that led to the burial chamber. The tomb of Horhotep is one of two non-royal funerary complexes at Thebes, which exceptional character can be seen in the number of its elements. Each of the most important rooms: the chapel and burial chamber, were carved in two copies. It could indicate two phases in the development of the complex. In the first one, structures based on the classic layout of rooms were carved in the rock, including the eastern cult chapel, the false burial chamber, and the actual burial chamber with the sarcophagus, together with the connecting corridors. The second phase is associated with the creation of the transverse corridor connecting the original chapel with the new elements carved in the western part. It could only be supposed that the rooms from the second phase belonged to a close member of Horhotep's family. Meketre's tomb may serve as an example of such a development of a burial complex in the Middle Kingdom. A second tomb was fashioned in the western portion of the one belonging to the official to contain the body of his son, Intef (MMA 1101/TT 280a). ${ }^{17}$

(Translation: B. Majchrzak)

\footnotetext{
${ }^{16}$ Chudzik 2016b: 71-80.

17 Winlock 1920: 16-18, Fig. 4.
} 


\section{References}

Allen, J.P. 1996: Some Theban Officials of the Early Middle Kingdom, [in:] Manuelian, P. Der (Ed.), Studies in Honor of William Kelly Simpson I, Boston, 1-26

Allen, J.P. 2003: The high officials of the early Middle Kingdom, [in:] Strudwick, N., Taylor, J.H. (Eds), The Theban Necropolis: Past, Present and Future, London, 14-29 Arnold, Di. 1971: Grabung im Asasif 1963-1970. I: Das Grab des Jnj-jtj.f. Die Architektur, ArchVer 4, Mainz a/Rhein

Arnold, Di. 2003: The Encyclopedia of Ancient Egyptian Architecture, London

Capart, J. (Ed.) 1936: Travels in Egypt (December 1880 to May 1881). Letters of Charles Edwin Wilbour, Brooklyn

Chudzik, P. 2015: The Tombs of Asasif: Archaeological exploration in the 2013/2014 season, PAM XXIV/1, 239-246

Chudzik, P. 2016a: Tajemnice egipskich grobowców/Secrets of Egyptian tombs, Wrocław Chudzik, P. 2016b: A unique royal mortuary temple and exceptional private complexes. The architecture of the Nebhepetre Mentuhotep II monument reflected in the funerary structures of high officials at Thebes, [in:] Ullmann, M. (Ed.), 10. Ägyptologische Tempeltagung: Ägyptische Tempel zwischen Normierung und Individualität, München, 29. - 31. August 2014, Wiesbaden, 71-80

Hayes, W.C. 1990: The Scepter of Egypt I: From the Earliest Times to the End of the Middle Kingdom, New York

Hölzl, R. 2005: Libation basins from the Old to the New Kingdom: Practical use and Religious Significance, [in:] Amenta, A., Luiselli, M.M., Sordi, M.N. (Eds), L'acqua nell'antica Egitto: vita, rigenerazione, incantesimo, medicamento. Proceedings of the first International conference for young egytologists, Italy, Chianciano Teme, October 15-18, 2003, Egitto antico III/1, Roma, 309-317

Lacau, P. 1904: Sarcophages antérieurs au Nouvel Empire I, Catalogue Général des Antiquités Égyptiennes du Musée du Caire Nos. 28001-28086, Le Caire

Maspero, G. 1889: Trois années de fouilles dans les tombeaux de Thèbes et de Memphis, [in:] MIFAO I, Paris, 133-242

Maspero, G. 1906: Guide to the Cairo Museum, Cairo

Sauneron, S. 2000: The Priests of Ancient Egypt, transl. by D. Lorton, London

Soliman, R. 2009: Old and Middle Kingdom Theban Tombs, London

Winlock, H.E. 1920: The Egyptian Expedition 1918-1920: II. Excavations at Thebes 1919-20, BMMA 15/12/2, 12-32

Winlock, H.E. 1923: The Museum's Excavations at Thebes, BMMA 18/12/2, 11-39

Winlock, H.E. 1942: Excavations at Deir el Bahri, 1911-1931, New York 


\section{ÉTUDES et TRAVAUX XXX / 2017}

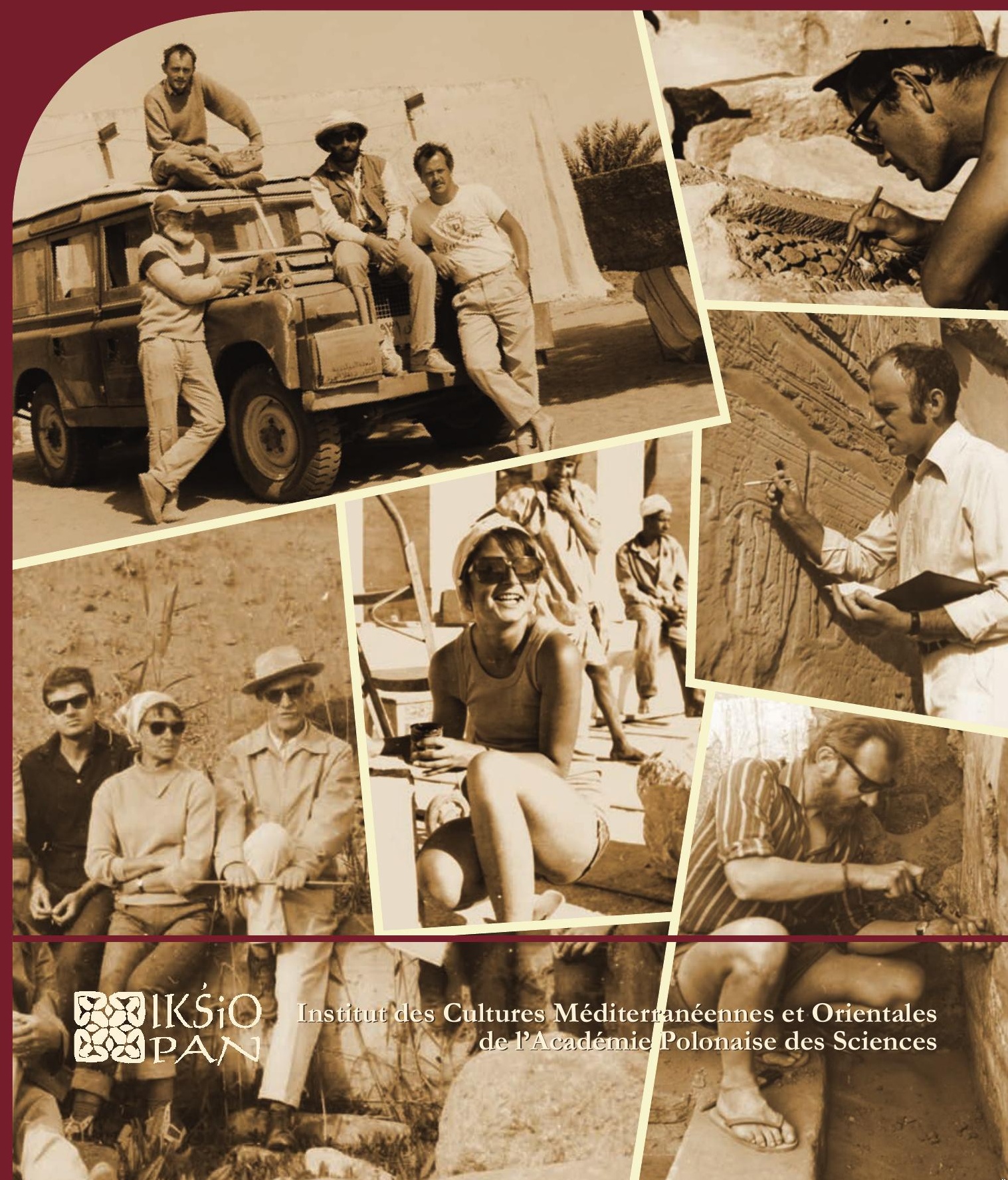




\title{
COMITÉ DE RÉDACTION SCIENTIFIQUE
}

Maciej Makowski - rédacteur en chef

Jadwiga Iwaszczuk - rédacteur et sécretaire de la rédaction

Mariusz Drzewiecki - rédacteur

Maciej G. Witkowski - rédacteur

\section{CONSEIL SCIENTIFIQUE DU JOURNAL}

M. Kobusiewicz (IAE PAS, Warszawa), E. Laskowska-Kusztal (IMOC PAS, Warszawa),

D. Michaelides (University of Cyprus, Nicosia),

J.Ch. Moretti (IRAA-MOM, Université de Lyon 2/CNRS),

D. Raue (Ägyptisches Museum der Universität Leipzig), P. Reynolds (ICREA, Barcelona),

D. Welsby (British Museum, London)

\section{COMITÉ SCIENTIFIQUE DE LECTURE}

J. Holaubek (Institut für Ägyptologie, Wien), S. Ikram (AUC, Cairo),

K. Innemée (Universiteit Leiden), J. McKenzie (Faculty of Oriental Studies, University of Oxford),

N. Strudwick (University of Cambridge), A. Loprieno-Gnirs (Universität Basel),

Ch.E. Loeben (Museen für Kulturgeschichte, Hannover), Y. Tristant (Macquarie University, Sydney),

V.W.J. van Gerven Oei (University of Aberdeen), A. Peignard-Giros (HiSoMA-MOM, Université de Lyon 2/CNRS), J.A. Ostrowski, E. Papuci-Władyka, J. Śliwa (IA JU, Kraków), R. Czerner (WUST, Wrocław), A. Ćwiek (IA AMU, Poznań), M. Wiewióra (IA NCU, Toruń), K. Domżalski

(IAE PAS, Warszawa), K.O. Kuraszkiewicz (DE FOS UW), M. Barwik, P. Bieliński, P. Dyczek, W. Godlewski, D. Ławecka, S. Rzepka, J. Żelazowski, M. Gawlikowski, J. Młynarczyk, A. Niwiński, T. Sarnowski, D. Szeląg, T. Waliszewski (IA UW, Warszawa)

\section{RÉDACTEUR THÉMATIQUE DU VOLUME \\ Barbara Lichocka}

\author{
AIDE RÉDACTION TECHNIQUE \\ Dorota Dobrzyńska, Mariusz Drzewiecki
}

REVUE DES TEXTES ANGLAIS

Jo Harper 
ÉTUDES et TRAVAUX XXX 
INSTYTUT KULTUR ŚRÓDZIEMNOMORSKICH I ORIENTALNYCH POLSKIEJ AKADEMII NAUK

\section{STUDIA i PRACE}

XXX

\section{Ro IKŚSiO \\ ESA PAN}

WARSZAWA

2017 
INSTITUT DES CULTURES MÉDITERRANÉENNES ET ORIENTALES DE L'ACADÉMIE POLONAISE DES SCIENCES

\section{ÉTUDES et TRAVAUX}

XXX

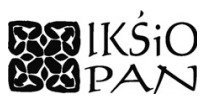

VARSOVIE

2017 
Publication scientifique financée dans le cadre du programme du Ministre de la Science et de l'Éducation Supérieure

« Programme National de Développement de l’Humanistique » pour les années 2016-2021 (projet no 3bH 150099 83)

\title{
HARODOWY PROGRAM ROZWOJU HUMANISTYKI
}

\author{
Copyright (C) \\ Instytut Kultur Śródziemnomorskich i Orientalnych PAN \\ et les Auteurs \\ Warszawa 2017
}

\author{
ISSN 2084-6762 \\ (avant $2011: 0079-3566$ ) \\ e-ISSN 2449-9579 \\ Version première en papier, imprimée en Pologne - 150 copies \\ Version électronique accessible sur \\ http://www.etudesettravaux.iksiopan.pl
}

Édition: Polskie Towarzystwo Historyczne et Wydawnictwo Neriton, Warszawa

Conception générale de couverture : J. Iwaszczuk

Photos de couverture : En haut, à gauche. Vieille Dongola 1991, S. Jakobielski

(debout à gauche), K. Pluskota (debout à droite), B. Żurawski (assis sur le camion)

et P. Wierzbicki (assis sur le camion) (de la collection de B. Żurawski)

En haut, à droite. Palmyre 1964, M. Marciniak au travail (phot. A. Dziewanowski)

Au centre. E. Laskowska-Kusztal au travail (de la collection de E. Laskowska-Kusztal)

En bas, à gauche. Tell Atrib 1962 ; de gauche : T. Biniewski, M. Marciniak, K. Kołodziejczyk,

K. Michałowski, A. Ostrasz, S. Jakobielski et S. Jasiewicz devant eux

(de la collection de IKŚSiO PAN).

En bas, à droite. Vieille Dongola 1976, S. Jakobielski nettoyant le mur (phot. M. Steinborn).

Au centre, à droite, K. Myśliwiec en train des travaux de documentation (de la collection de IKŚiO PAN) 


\section{Table des matières}

BARBARA LICHOCKA

Ergon agathon

Hartwig Altenmüller

$\mathrm{Zu}$ den Feindbildern auf den Zauberstäben des Mittleren Reiches und der Zweiten

Zwischenzeit

Nathalie Beaux

Des $m s w n s w$ de Thoutmosis III à Deir el-Bahari

Briant Bohleke, Nigel Strudwick

A Label for Opening of the Mouth Implements from the Burial of Senneferi (TT99)

and Remarks on the Ritual

Rosa Maria Bonacasa Carra, Nicola Bonacasa

Nuovi dati sugli edifici termali di Sabratha

EDWARD BROVARSKI

A Fragmentary Carrying Chair Scene in Salt Lake City, Utah

Julia Burdajewicz

Wall Painting Decoration from the North-West Church in Hippos-Sussita

of the Decapolis

Mariusz BURDAJEWICZ

From Pagan Temple to Church in Late Antiquity Palestine. A View from

Hippos-Sussita

MAREK ChlodNicki

Early Dynastic Bead Workshops at the Central Kom of Tell el-Farkha.

Patryk ChudziK, Mariusz Caban

Observations on the Architecture of the Tomb of Horhotep in Western Thebes

Krzysztof M. Cialowicz

New Discoveries at Tell el-Farkha and the Beginnings of the Egyptian State.

Amr EL-TiebI

Four Wooden New Kingdom Female Statuettes in the Egyptian Museum, Cairo 


\section{Naguib KanaWATI}

Ritual Marriage Alliances and Consolidation of Power in Middle Egypt during the Middle Kingdom

Adam Łajtar, Jolanta Mlynarczyk

A Faction Acclamation Incised on a Pithos Found Near the North-West Church at Hippos (Sussita)

Adam ŁaJTAR, Grzegorz OchaŁa

Two Private Prayers in Wall Inscriptions in the Faras Cathedral

Adam Łajtar, Anna Poludnikiewicz

Medicinal Vessels from Tell Atrib (Egypt)

JaCeK Michniewicz, Jolanta MlynarczyK

Petrographic Variability of the Fabrics of Wine Jars from Sha'ar-Ha Amakim as a Reflection of Differences in Their Provenance and Chronology

Iwona ModrzewsKa-PianetTI

Les importations d'amphores Dressel 20 en Gaule Cisalpine

Arthur SEgal

Samaria-Sebaste. Portrait of a polis in the Heart of Samaria 409

JOACHIM ŚLIWA

The Motif of a 'Blind Harper' in an Unexpected Place

MONIKA WIĘCH

Searching for the Kitchen in the Early Roman Phase of the 'Hellenistic' House at Nea Paphos (Cyprus)

Abréviations 
THE VOLUME IS PUBLISHED TO CELEBRATE

THE $60^{\text {TH }}$ ANNIVERSARY

OF THE ESTABLISHMENT OF

THE RESEARCH CENTRE FOR MEDITERRANEAN ARCHAEOLOGY POLISH ACADEMY OF SCIENCES

FOUNDED IN 1956

WHOSE MISSION IS CONTINUED BY

THE INSTITUTE OF MEDITERRANEAN AND ORIENTAL CULTURES

OF THE POLISH ACADEMY OF SCIENCES 